\title{
NOTES ON THE GENUS CEPHALEUTHERUS OF RAFI. NESQUE, AND OTHER RAYS WITH ABERRANT PECTORAL FINS (PROPTERYGIA AND HIEROPTERA).
}

\author{
By Theodore Gill, LL. D.
}

In A RECEnT article on "The Nomenclature of the Myliobatidie or Aëtobatidæ," I retained the names Myliobatis and Aëtobatis with a proviso. Adopting temporarily the views of Agassiz, I remarked:

This, it seems to me, is a perfectly legitimate view and use of the two names. Both names, Aëtobatus and Myliobatis, might have been retained for different sections of the old genus, if no other considerations had forbidden. Both of those names, however, as President Jordan has reminded me, were anticipated by a name given by Rafinesque in 1810.

CEPHALEUTHERUS.

Rafinesque, in his "Indice d'Ittiologis Siciliana," has the genus Cephaleutherus interposed between his Mobula (=Cephaloptera Dum.) and Vroxis (Trygon auct.), which, according to Dr. Jordan, is a Myliobatis. It is not, however, mentioned by Doderlein in his very full synonyms of the Myliobatids of the Mediterranean, and the book in question can not be found. While I have little doubt that Dr. Jordan is correct in his identification, and that the name Cephaleutherus should be taken for Myliobatis, I defer doing so until I am able to consult the "Indice" or a copy of it. Meanwhile I retain the name Myliobatis, but adopt for the family Aëtobatide.

Since that publication, Dr. Jordan kindly sent me a copy of the description of Cephaleutherus, and the "Indice d'Ittiologia Siciliana" was found. These data have compelled me to refuse to adopt Cepha. leutherus as a substitute for Myliobatis, and led me to consider that nominal genus to have been based on a teratologic specimen exhibiting an arrest of development. Rafinesque's description follows:

Gen. Cephaleutherus. Capo sciolto, e diviso dall' ale laterali, occhi, e 'spiragli uniti, e situati al lato del capo, due ale sopra la coda, nessuna alia sua estremità. Osserv. Questo genere è rimarchevolissimo, a motivo del carattere che offerisce il suo capo sciolto, il quale è unito all' ale laterali ossiano pettorali, in tutti gli altri generi vicini.

Sp.n. Cephaleutherus maculatus. Fulvastro al disopra con delle macchie fosche, bianchiccio al di sotto, capo appuntato, ale laterali anteriori, appuntate, e scabre anteriormente, un ordine di spine sopra la Schiena, e tre sopra la coda, che è acuta. Osserv. Hà alcune spine disposte regolarmente sopra il capo, e dietro gli occhi, la bocca è situata sotto il capo, ed in un fosso, e le aperture branchiali sono sotro la 
parte anteriore del corpo, cinque da ogni lato; frà le ale laterali anteriori, à posteteori vi è un appendice quasi digitato alla punta, l' ano è più vicino del capo, che della punta della coda, questa è convessa al disopra, e piana al disotto, e le ale, che porta, sono molto vicine alla sua estremita, approssimate frà esse, e con una spina frà il mezzo.

A free head separated from the pectoral fins, and the lateral eyes and spiracles, are characteristic features of myliobatoid rays, and these attributes have evidently led Dr. Jordan to identify Cephaleutherus maculatus with Myliobatis bovinus, but other characters assigned to the species are in direct contravention of such an identification. Such are the two dorsal fins (due ala sopra la cauda), the approximation of those fins to the end of the tail (molto vicine alla sua estremità) and to each other (approssimata frà esse), the distinct anterior lobes of the ventrals (frà le ale laterali anteriori e posteriori vi è un appendice quasi digitato alla punta), the pointed snout (capo appuntato), the pectoral fins pointed and scabrous anteriorly (ale laterali anteriori appuntate e scabre anteriormente), the row of spiny bucklers along the middle of the back, the spines elsewhere, and the dark yellowish back with blackish spots (fulvastro al disopra con delle macehie fosche). These (and other characters mentioned) are not shared by Mediterranean Myliobatids, but are by different skates. The ray described by Rafinesque appears indeed to have been a true skate (apparently Raja clavata), but the notice of the distinct head indicates that there was something anomalous about it. What, then, was it?

There is a liability in any skate to an arrest of development in the growth of the pectoral fins forward and consequently their continuity with the head, but in most of such cases there is an independent extension forward from the base of the pectorals. Such anomalies have received generic names, Propterygia having been proposed for one phase of development and Hieroptera for another. An analogous phase was probably manifest in the specimen noticed by Rafinesque, and appears to be noticed in the terms "ale laterali anteriori appuntate e seabre auteriormente," which may be interpreted as referring to pectoral fins pointed forward. In such cases, the head is distinct from the pectorals, and the eyes and spiracles more nearly lateral, although not lateral to the degree manifest in Myliobatids. The anomalies represented by the generic names Propterygia and Hieroptera were described by Otto and Fleming.

II.

The Propterygia of Otto._-Otto, in 1818, obtained a ray in Scotland (New Haven), and in 1820 described it as a new generic type-Propterygia hyposticta. The genus was defined as follows:

Raja; altero pinnarum pectoralium pari ad latera capitis a corpore distincti et in rostrum subacuminatum desinentis; spiracula quinque; ${ }^{\prime}$ canda brevis absque aculeo. 
The description and figure of Otto represent a skate (Raia intermedia?) with pectoral fins distinct from the head, nevertheless with imperfect cephalic appendages.

A similar monstrosity is noticed and figured in Richardson's edition of Yarrell's History of British Fishes, ${ }^{1}$ with the caption, "A monstrous thornback maid,"-that is, Raia clavata.

III.

The Hieroptera of Fleming.-In 1841, the Reverend Dr. John Fleming gave a "Description of a Species of Skate new to the British Fauna." To him it "appears sufficiently evident that this skate can not be referred to any known British species. The form of the snout, of the ventrals, and of the spines, and the distribution of the latter on the back and tail, furnish satisfactory distinguishing characters. But above all the peculiar anterior prolongation of the pectoral fins, their symmetrical character precluding the notion of monstrosity, justify the belief that it is a new European form, and entitled to be regarded as the type of a new genus, which [he says] I propose to term Hieroptera (เspos, sacerdos, and $\pi \tau \varepsilon \rho o v$, ala); and I further propose to designate the present species by the trivial name of Abredonensis, to mark the particular locality [Aberdeen Bay] where it was first observed. The newest of the modern genera to which it approaches is perhaps the Propterygia of Professor Otto, the relationship to which immediately suggested itself to that profound ichthyologist, Professor Agassiz, when [Fleming remarked] I showed him the specimen during the visit with which he favored me in October last (1840). It differs, however, from the Propterygia in the condition of the pectorals anteriorly, and in the absence of those lateral processes or finlets which occur on each side of the head opposite to the eyes."

The reverend doctor evidently had some peculiar ideas about monstrosities and their asymmetrical character, and probably such ideas prevented him from recognizing his specimen as the monstrosity which his mind appears to have considered. The Hieroptera, however, did denote a monstrosity, apparently representing a still greater arrest of development of the pectoral fins than Propterygia, and a complete absence of cephalic fin elements.

Fleming's specimen was apparently a form of Raia clavata.

The Hieroptera stage was probably that exemplified by Rafinesque's skate. It was also represented by a specimen described and illustrated by Dr. Louis Bureau in an article "Sur une monstrosite de la Raie estellée, Raia asterias, ${ }^{2}$ Rond."

${ }^{2}$ Bull. Soc. Zool. France, XIV, pp. 313-316, 1889. 


\section{IV.}

The Propleygia of Gray.-Gray, in 1851, ciied the name Propleygia, Otto, in the synonymy of the genus Raja, but without reference to place of publication or date. Propleygia is, of course, merely a slip for Propterygia. The statement is made that the nominal genus "is founded on a monstrosity rather frequent among the Rays."

$$
\text { V. }
$$

The various names that have been given to the monstrosity, or stages of arrest of development, of the pectoral fins may be combined here:

$$
\text { CEPHALEUTHERUS PHASE. }
$$

Cephaleutherus, Rafinesque, Indice Ittiol. Sicil., p. 61, 1810.

Hieroptera, Fleming, Edinburgh New Phil. Journ., XXXI, p. 236, pls. 4, 5, 1841.

PROPTERYGIA PHASE.

Propterygia, Otтo, Nova Acta Acad. Caes. Leop. Car. Nat. Cur., X, p. 111, pls. 5, 6, 1820; Couspectus Animal., 1821 (fide Fleming).

Propleygia, Oтто, fide Gray, List Fish. Brit. Mus., I, p. 105, 1851 (misprint?).

VI.

The Ictaetus of Rafinesque.-Although Cephaleutherus, as has been shown, was not identical with Myliobatis, one of Rafinesque's genera was, in all probability. In his "Analyse de la Nature" the name Ictaetus, Raf., occurs between Mobula, Raf., and Cephaleutherus, Raf., and this is doubtless merely a Greek equivalent of "Eagle-ray," a quasi-popular designation of Myliobatis. Ictaetus is, however, a pure nomen nudum, and can not therefore be revived. 


\section{$2 \mathrm{BHL}$ Biodiversity Heritage Library}

Gill, Theodore. 1896. "Notes on the genus Cephaleutherus of Rafinesque, and other rays with aberrant pectoral fins (Propterygia and Hieroptera)." Proceedings of the United States National Museum 18(1054), 195-198. https://doi.org/10.5479/si.00963801.18-1054.195.

View This Item Online: https://www.biodiversitylibrary.org/item/32799

DOI: https://doi.org/10.5479/si.00963801.18-1054.195

Permalink: https://www.biodiversitylibrary.org/partpdf/5700

\section{Holding Institution}

Smithsonian Libraries

\section{Sponsored by}

Smithsonian

\section{Copyright \& Reuse}

Copyright Status: NOT_IN_COPYRIGHT

This document was created from content at the Biodiversity Heritage Library, the world's largest open access digital library for biodiversity literature and archives. Visit BHL at https://www.biodiversitylibrary.org. 